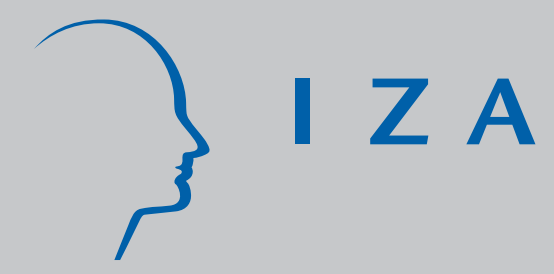

IZA DP No. 1835

Health Determinants in Urban China

Zhong Zhao

November 2005 


\title{
Health Determinants in Urban China
}

\author{
Zhong Zhao \\ IZA Bonn \\ and CCER, Peking University
}

Discussion Paper No. 1835

November 2005

\author{
IZA \\ P.O. Box 7240 \\ 53072 Bonn \\ Germany \\ Phone: +49-228-3894-0 \\ Fax: +49-228-3894-180 \\ Email: iza@iza.org
}

\begin{abstract}
Any opinions expressed here are those of the author(s) and not those of the institute. Research disseminated by IZA may include views on policy, but the institute itself takes no institutional policy positions.

The Institute for the Study of Labor (IZA) in Bonn is a local and virtual international research center and a place of communication between science, politics and business. IZA is an independent nonprofit company supported by Deutsche Post World Net. The center is associated with the University of Bonn and offers a stimulating research environment through its research networks, research support, and visitors and doctoral programs. IZA engages in (i) original and internationally competitive research in all fields of labor economics, (ii) development of policy concepts, and (iii) dissemination of research results and concepts to the interested public.
\end{abstract}

IZA Discussion Papers often represent preliminary work and are circulated to encourage discussion. Citation of such a paper should account for its provisional character. A revised version may be available directly from the author. 
IZA Discussion Paper No. 1835

November 2005

\section{ABSTRACT}

\section{Health Determinants in Urban China ${ }^{\star}$}

This paper identifies health determinants in urban China applying Grossman model. Using wave of China Health and Nutrition Survey in 2000, we find that education has important positive effect on health, and cost of health care services has significantly negative impact. However, effects of wage rate and household income are insignificant. We also find that region is an important determinant of health. The body weight is also important, but unlike finding in developed countries, under-weight instead of over-weight is a better predictor for poor health. Our results suggest that male has better health than female does, and married couple has better health in urban China.

JEL Classification: I12, J24, D12

Keywords: $\quad$ self-reported health status, Grossman model, ordered probit, China

Corresponding author:

Zhong Zhao

Institute for the Study of Labor (IZA)

Schaumburg-Lippe-Str. 7 / 9

53113 Bonn

Germany

Email: zhao@iza.org

\footnotetext{
* I would like to thank participants at the 2005 Annual Conference of Chinese Economists Association for helpful comments, and thank Hongchun Zhao for excellent research assistance. Financial supports from China Medical Board of New York (CMB), China Academy of Health Policy (CAHP) and a 211 project at Peking University are acknowledged. All errors are the sole responsibility of mine.
} 


\section{Health Determinants in Urban China}

\section{Introduction}

Health is widely considered as an important component of human capital. Since the seminal work of Grossman (1972), Grossman model has become standard model to study health demand and health determinants. Applying Grossman model, economists have carried out numerous empirical studies, for examples: Wagstaff (1986, 1993), Erbsland et al. (1995), Sickles and Yazbeck (1998), and Dustmann and Windmeiher (2000) among others. However, few studies on health issues in China are based on human capital theory. ${ }^{1}$

In this paper, we use China Health and Nutrition Survey (CHNS) data set to study the health demand in urban China. We focus on two issues: one is using Chinese data to test Grossman model, and the other is identifying main determinants of health in urban China.

We find that education has important positive effect on health, cost of health care services has significantly robust negative impact, but effects of wage rate and household income are insignificant.

The relationship between age and health is nonlinear. At young age, health increases with age, but is peaked around age 40. This implies that people should pay more attention to their health starting from a relatively young age.

Region, gender, marriage status and body weight are also important factors. Region is an import determinant of health. People in western provinces have worst health; people in coastal and northeastern provinces have best health. Gender and marriage status are also important. Male has better health than female has; married couple has better health. Unlike finding in developed countries, e.g. Gerdtham and

\footnotetext{
${ }^{1}$ Liu et al (2004) is one of few exceptions. They study the relationship between economic growth and health capital.
} 
Johannesson (1999), under-weight instead of over-weight is a better predictor for poor health.

The remaining paper is organized as follows: Section 2 outlines the analytical framework and specifies the econometric models, Section 3 describes the data set and the health status variable, Section 4 presents descriptive statistics and empirical results, and Section 5 concludes the paper.

\section{Analytical Framework}

\subsection{Grossman Model}

Economists consider health as human capital for a long time, e.g. Mushkin (1962), Becker (1964) and Fuchs (1966). Building on the human capital theory, Grossman (1972) provides a formal model to analyze health capital. According to the approach of Grossman, the main distinction between health and education is that health increases income through adding healthy working days while education through improving productivity.

Following the standard model of Grossman (1972, 2000), we assume that the utility function of a representative consumer is as follows:

$$
U=U\left(\phi_{t} H_{t}, Z_{t}\right), t=0,1, \ldots, n
$$

where $H_{t}$ is the stock of health capital at time $t, \phi_{t}$ is benefit produced by one unit of health capital, $h_{t}=\phi_{t} H_{t}$ is the health consumed at time $t$, and $Z_{t}$ is consumption for other goods at time $t$.

The initial stock of health capital $H_{0}$ is exogenous. $H_{t}$ at other time and the length of life $n$ are endogenous. The following equation describes the change of health capital.

$$
H_{t+1}-H_{t}=I_{t}-\delta_{t} H_{t}
$$


where $I_{t}$ is the investment in health and $\delta_{t}$ is the rate of depreciation of health capital at time $t . \quad \delta_{t}$ is changing with age.

$I_{t}$ and $Z_{t}$ are produced by the following equations:

$$
\begin{aligned}
& I_{t}=I_{t}\left(M_{t}, T H_{t} ; E\right) \\
& Z_{t}=Z_{t}\left(X_{t}, T_{t} ; E\right)
\end{aligned}
$$

where $M_{t}$ are market goods, such as health care services, which are used to produce $I_{t} \cdot T H_{t}$ is the time allocated to improve health. $E$ is other exogenous component of human capital besides health, such as education. Equation (4) is home-production function for other consumption items $Z_{t} \cdot Z_{t}$ are produced by market goods $X_{t}$, time $T_{t}$ and other human capital $E$.

Furthermore, the consumer faces the following budget constraint:

$$
\sum_{t=0}^{n} \frac{P_{t} M_{t}+Q_{t} X_{t}}{(1+r)^{t}}=\sum_{t=0}^{n} \frac{W_{t} T W_{t}}{(1+r)^{t}}+A_{0}
$$

where $P_{t}$ and $Q_{t}$ are prices, $W_{t}$ is wage rate, $T W_{t}$ is hours of work, and $A_{0}$ is initial wealth.

Beside budget constraint, the consumer also needs to meet the time constraint $\Omega$. $\Omega$ must be used up at each period as following:

$$
T W_{t}+T H_{t}+T_{t}+T L_{t}=\Omega
$$

where $T W_{t}$ is time for working, and $T L_{t}$ is time loss due to illness.

Equations (1) to (6) constitute the Grossman model and they jointly determine the demand for health.

\subsection{Static Analysis and Econometric Specifications}

Based on the above model, we can study the demand for health through two approaches: Pure Investment Model and Pure Consumption Model. Grossman(2000) 
has stressed "the estimation of the investment model rather than the consumption model because the former model generates powerful predictions from simple analysis and less innocuous assumptions.” This paper is based on pure invest model. The optimal condition of this model is:

$$
\frac{G_{t} W_{t}}{\pi_{t-1}}+\frac{G_{t}\left[\left(\frac{U_{h t}}{m}\right)(1+r)^{t}\right]}{\pi_{t-1}}=r+\delta_{t}
$$

where $G_{t}=\partial T L_{t} / \partial H_{t}$ is the marginal product of health capital, $U_{h t}=\partial U / \partial H_{t}$ is marginal utility directly produced by health, $m$ is marginal utility produced by monetary income, and $\pi_{t-1}$ is the shadow price of health, which is determined by the cost of health care services, wage rate, etc.

Condition (7) is similar to other optimal conditions in economics. Namely, it means that marginal benefit equals marginal cost. The benefit of health includes two aspects: one is monetary benefit, i.e. $G_{t} W_{t} / \pi_{t-1}$, and the other is utility gain from health, i.e. $\left(G_{t}\left[\left(U_{h t} / m\right)(1+r)^{t}\right] / \pi_{t-1}\right)$. Cost is the same as cost incurred on other standard investment, including interest and depreciation.

Equation (7) provides a series of testable hypotheses. As in Figure 1, the crossing point of health benefit curve $\left(G_{t} W_{t} / \pi_{t-1}+G_{t}\left[\left(U_{h t} / m\right)(1+r)^{j}\right] / \pi_{t-1}\right)$ and cost curve $\left(r+\delta_{t}\right)$ determines the optimal demand for health $H_{t}^{*}$. If the cost increases, the demand for health will decrease.

In the literature, the change of the rate of depreciation $\delta_{t}$ is one focal point. It is usually assumed that $\delta_{t}$ is increasing with age. If $\delta_{t}$ increases to $\delta_{t}^{*}$, the demand for health will reduce from $H_{t}^{*}$ to $H_{t}^{* a}$.

Education is another key variable. Health and education are two types of complementary human capital. Increase of education will improve the health since 
more educated consumer will produce health less costly, and hence will lower the shadow price of health, which in turn will increase the health demand from $H_{t}^{*}$ to $H_{t}^{* b}$.

Health care service is one of the main inputs of health. If its price increases, the cost of health will inevitably increase, and will decrease the demand for health.

Wage rate reflects the value of time. On the one hand, if wage rate increases, the earning from healthy working days will also increase. On the other hand, production of health need time, increase of the wage rate makes the production of health more costly. Therefore, the impact of wage rate on the health demand is ambiguous. However, people generally believe that the former effect dominates the later effect, and that wage rate should have a positive effect.

The time constraint also has testable implication. If the consumer works more, he will end up with less time to improve his health, so his health will decrease.

Our empirical study will test above theoretical implications. The basic specification is as following: ${ }^{2}$

$$
\begin{gathered}
\text { health }=\beta_{0}+\beta_{1} \text { age }+\beta_{2} \text { wage }+\beta_{3} \text { worktime }+ \\
\beta_{4} \text { healthprice }+\beta_{5} \text { education }+\varepsilon
\end{gathered}
$$

Age is used as a proxy for rate of depreciation. Wage rate and price of health care services reflect the shadow price of health. We estimate different variations of equation (8) in our study. We also control other factors such as gender, marriage status and region in Section 4.

\footnotetext{
2 There are two reasons we adopting a linear model instead of a double logarithm model derived from Grossman model. One is that the study of Wagstaff (1993) finds that the assumption $\left(\widetilde{H}_{t} / \delta_{t-1}=0\right)$ is unconvincing and that linear model is more consistent with data. The other is that we use ordered probit model to analyze ordered categorical health status variable.
} 


\section{Data Set and Measurement of Health}

\subsection{CHNS Data Set}

The data set is the China Health and Nutrition Survey (CHNS). CHNS is a longitudinal survey, which includes five waves in 1989, 1991, 1993, 1997 and 2000. The survey covers coastal, middle, northeastern and western provinces in China. ${ }^{3}$

CHNS utilizes a multistage, random cluster-sampling scheme. In each province, both big cities and small cities are sampled. CHNS also includes cities from different income levels, and surveys both rural and urban residents. CHNS has very rich information on health and nutrition. It provides a valuable national sample for researchers in health and nutrition fields.

Our econometric approach in this paper is reduced form cross-sectional analysis. We focus our study on the latest wave of the data, 2000 survey, which includes 15,648 observations. There is significant difference between urban area and rural area in China, so we restrict our attention on the urban residents. Since Grossman model is based on working adults, our final sample only includes urban residents with age from 18 to 55. The final sample used in this paper has 1,977 observations. Among them 1,043 are female, and 1,356 are working adults.

\subsection{Self-Reported Health Status}

One of the major difficulties to study health determinants is how to measure the health. In the literature, there are many methods, like Quality-adjusted Life Years (see Cutler and Richardson, 1997), Disability-adjusted Life Years (see World Bank, 1993) and Quality of Well-being Scale (see Kaplan and Anderson, 1988). Field and Gold (1998) provide an excellent survey.

In the CHNS data set, the people are asked to self-report their health status in four categories: poor, fair, good and excellent. In this paper, instead of using continuous

\footnotetext{
3 The surveys of 1989, 1991 and 1993 include Guangxi, Guizhou, Henan, Hubei, Hunan, Jiangshu, Liaoning and Shangdong 8 provinces. In 1997, Heilongjiang replaces Lianing. In 2000, both Liaoning and Heilongjiang are included in the survey along with other provinces.
} 
measurement, we use discrete measurement, self-reported status as our health measurement, as in Gerdtham and Johannesson (1999). Of course, this measurement is not perfect, but compared with continuous measurement, one advantage of categorical measurement is that in some degree it can mitigate measurement error problem. ${ }^{4}$ Since we are dealing with ordered discrete variable, we choose ordered probit model for our empirical analysis.

\section{Empirical Results}

\subsection{Descriptive Statistics}

Table 1 is descriptive statistics on self-reported health status. $21.0 \%$ of urban adult residents report to have excellent health, but for female population, only $16.8 \%$ report to have excellent health. People in Guangxi and Guizhou (western provinces) have lowest percentage of excellent health status. They are $6.0 \%$ and $5.7 \%$, respectively. People in Heilongjiang, Liaoning (northeastern provinces), Jiangsu and Shangdong (coastal provinces) have highest percentage of excellent health (around 30\%). The difference is striking. However, if we combine excellent health and good health two categories, the gap between western provinces and other provinces is becoming smaller. In all provinces, less than 5\% people report to have poor health. From Table 1, we also can see except Liaoning, all other provinces report higher percentages of excellent health status in small cities.

\subsection{Econometric Results}

Table 2 summarizes the variables used in the ordered probit analysis. Table 3 and Table 4 are estimates from ordered probit models for the whole sample.

\footnotetext{
${ }^{4}$ Studies, such as Kaplan and Camacho (1983), find this categorical health variable contains important information on individual's health.
} 
Table 3 reports results from basic models. The basic models include key variables in Grossman model, such as age (proxy for rate of depreciation), education, marriage status, health insurance dummy and cost of a flu treatment (proxy for the cost of health care services). ${ }^{5}$ The last two variables reflect the shadow price of health. In order to accommodate the nonlinearity of age, we adopt two approaches. One is using age, age squared and age cubed, and the other is using age group dummies. From Table 3, it is clear that the effect of age is highly nonlinear, and age group dummies can capture the nonlinear relationship between age and health better.

As shown in Table 3, compared to age group of 18 to 22, age groups of 23 to 30, 31 to 35 and 36 to 40 have better health. After 40, the health is deteriorating with age. The effect of age on health comes from two sources: increasing of depreciation rate of health capital and decreasing of benefit period from investing in health. Both sources negatively affect the demand for health.

In the basic model, the effect of education is significantly positive for the whole population, as well as for male and for female.

The cost of health care services (using cost of a flu treatment as proxy) has negative but insignificant effect on health for the whole population, as well as for male and for female separately.

We also find that female's health is significantly worse than male's. Both married male and female have better health than their single counterparts do. The effect of household size is also positive but only significant for male.

In Table 4, we control for additional factors, such as region, city size, income level of the cities, and province dummies. The findings on age and education from basic models remain unchanged. However, the effect of household size becomes

\footnotetext{
${ }^{5}$ We use the community cost instead of individual cost to avoid the problem that individual cost is only observed for the people who have a cold.
} 
significantly positive. The effect of cost of a flu treatment becomes significantly negative for the whole population as well as for male. This is consistent with the prediction from Grossman model.

Region is an important determinant of health. Compared to Henan province (located in the middle part of China), western provinces (Guangxi and Guizhou) have worse health, but coastal provinces (Shangdong and Jiangsu) and northeastern provinces (Liaoning and Heilongjiang) have better health. Provinces (Hubei and Hunan) in the same region as Henan have similar health status as Henna has.

We also consider city characteristics. Big city is not an important factor to determinate the health for male. We divide the city into three groups according to income level: high-income city, middle-income city and low-income city, and include high-income city dummy and middle-income city dummy in our estimation. For the whole population as well as for male and for female separately, the coefficients of middle-income city dummy are significantly positive. Nonetheless, the coefficients of high-income city dummy are all insignificant. One interpretation is that the health care services are inadequate in low-income cities. So compared to residents in the low-income city, the residents in the middle-income cities have better health. Meanwhile, the working pressure is very high in high-income cities, and the residents in high-income cities focus more on working, and less on health and leisure., ${ }^{6,7}$

In Table 5, we restrict our analysis on the working sample only. For the working sample, we also control for wage rate, hours of work, and type of work. We find wage rate, hours of work and working in the formal sector are all insignificant, albeit all of

\footnotetext{
${ }_{7}^{6}$ Another explanation in the literature is that urbanization increases the depreciation rate of health.

${ }^{7}$ In this specification, we do not include body mass index (MBI) since BMI is an endogenous variable. Nonetheless, in order to compare our results with findings in the literature (e.g. Gerdtham and Johannesson, 1999), we also run model with over-weight and under-weight dummies defined by BMI. Unlike findings in developed countries, we find under-weight instead of over-weight is a better predictor for poor health in urban China. The coefficient of over-weight dummy is insignificantly positive. This is not surprising since China is a developing country. Ill nutrition is still a major cause for poor health. These estimates are not reported here and are available from the author upon request.
} 
them are positive. The inconsistency between our findings on wage rate with common wisdom is not surprising given that the primary health care in urban China is part of government welfare program. Non-market forces mainly drive the health investment decisions of urban residents. Further more the effect of wage rate goes to two directions, and from theory the effect of wage rate is ambiguous.

We also run separate regressions for people in the formal sector and in the informal sector. Results for these two groups are similar (see Table 6).

\section{Conclusion Remarks}

Applying Grossman model, we study the health determinants for Chinese urban adult population based on self-reported categorical health status.

We find cost of health care services has significantly negative impact on health. This finding is very robust across different model specifications investigated in this paper.

Effect of education on health is significantly positive. The positive relationship between health and education is also robust. This positive relationship means that it is possible to use education as a practical tool to improve the health of the population. Investing in education level not only increase productivity and increases income, but also improves the health status; meanwhile health is found positively correlated with income (Liu, et al. 2004). When formulating human capital policy, it will be fruitful to consider health and education together.

To interpret the result on education, it is necessary to point out that in our analysis we cannot model unobservable factors such as ability. If the correlations between ability and education and between ability and health are both positive, our result on education will be bias upward due to omitted variable bias (see Grossman, 2000). 
Our study shows that health is deteriorating with age starting from around age 40 . This finding is striking in the sense that even if we are still "young”, our health is starting deteriorating. An important policy implication is that after certain age, we should have regular physical examination. On the one hand, examination can find the illness at earlier stage, so it helps to slow down the health deteriorating speed; on the other hand, it can save the money from future treatment.

Our empirical findings on education, age and cost of health services are consistent with the predictions from Grossman model.

Wage rate or income on the health is also positive but insignificant. Our findings are not surprising given that the primary health care in urban China is part of government welfare program. Non-market forces mainly drive the health investment decisions of urban residents. Further more the effect of wage rate goes to two directions, and from theory the effect of wage rate is ambiguous.

Contrary to finding in developed countries, under-weight instead of over-weight is a better predictor for poor health. We also find Region is an import determinant of health. Western provinces have worst health; coastal and northeastern provinces have best health. Male has better health than female has, and married couple has better health.

The econometric approach adopted here is reduced form cross-sectional analysis. This is our first attempt to estimate and to test Grossman model using Chinese data. In the future studies, we will explore structural model approach and consider the role of life-cycle behavior. 


\section{References}

Becker, G. S. (1964), “Human Capital,” Columbia University Press for the National Bureau of Economic Research, New York.

Cutler, D. M. and E. Richardson (1997), "Measuring the Health of the U.S. Population,” Brookings Papers on Economic Activity: Microeconomics 1997, 217-271.

Dustmann, C. and F. Windmeijer (2000), "Wages and the Demand for Health-A Life Cycle Analysis,” The Institute for the Fiscal Studies, Working Paper Series No. W99/20.

Erbsland, M., W. Ried and V. Ulrich (1995), "Health, Health Care, and the Environment, Econometric Evidence from German Micro Data,” Health Economics, Vol. 4, 169-182.

Field, M. J. and M. R. Gold (1998), “Summarizing Population Health: Directions for the Development and Application of Population Metrics,” National Academy Press, Washington, D.C. 1998.

Fuchs, V. R. (1966), "The Contribution of Health Services to the American Economy,” Milbank Memorial Fund Quarterly, Vol. 66, 65-102.

Gerdtham, U-G. and M. Johannesson (1999), “New Estimates of the Demand for Health: Results Based on a Categorical Health Measure and Swedish Micro Data”, Social Science and Medicine, Vol. 49, Issue 10, 1325-1332.

Grossman, M. (1972), “On the Concept of Health Capital and the Demand for Health,” Journal of Political Economy, Vol. 80, 223-55.

Grossman, M. (2000), “The Human Capital Model of the Demand for Health,” Chapter 7, in Handbook of Health Economics, eds. J. P. Newhouse and A. J. Culyer, Amsterdam: Elsevier Science. 
Kaplan, R. and J. P. Anderson (1988), “A General Health Policy Model: Update and Applications,” Health Services Research, Vol. 23, No. 2, 203-235.

Kaplan, R. and T. Camacho (1983), “Perceived Health and Mortality: A Nine-Year Follow-up of the Human Population Laboratory Cohort,” American Journal of Epidemiology, Vol. 117, 292-304.

Liu, G. G., W. H. Dow, A. Z. Fu and J. Akin (2004), "Health Human Capital and Income Growth in China,” China Economic Quarterly, Vol.4, Issue 1, 101-118.

Mushkin, S. J. (1962), “Health as an Investment,” Journal of Political Economy, Vol. 70, 129-157.

Sickles, R. C. and A. Yazbeck (1998), “On the Dynamics of Demand for Leisure and the Production of Health,” Journal of Business and Economic Statistics, Vol. 16, No. 2, 187-197.

Wagstaff, A. (1986), “The Demand for Health: Some New Empirical Evidence,” Journal of Health Economics, Vol. 5, 195-233.

Wagstaff, A. (1993), “The Demand for Health: An Empirical Reformulation of the Grossman Model,” Health Economics, Vol. 2, 189-198.

World Bank (1993), “World Development Report 1993: Investing in Health,” Oxford, UK: Oxford University Press. 
Figure 1. Static Analysis for Health Demand

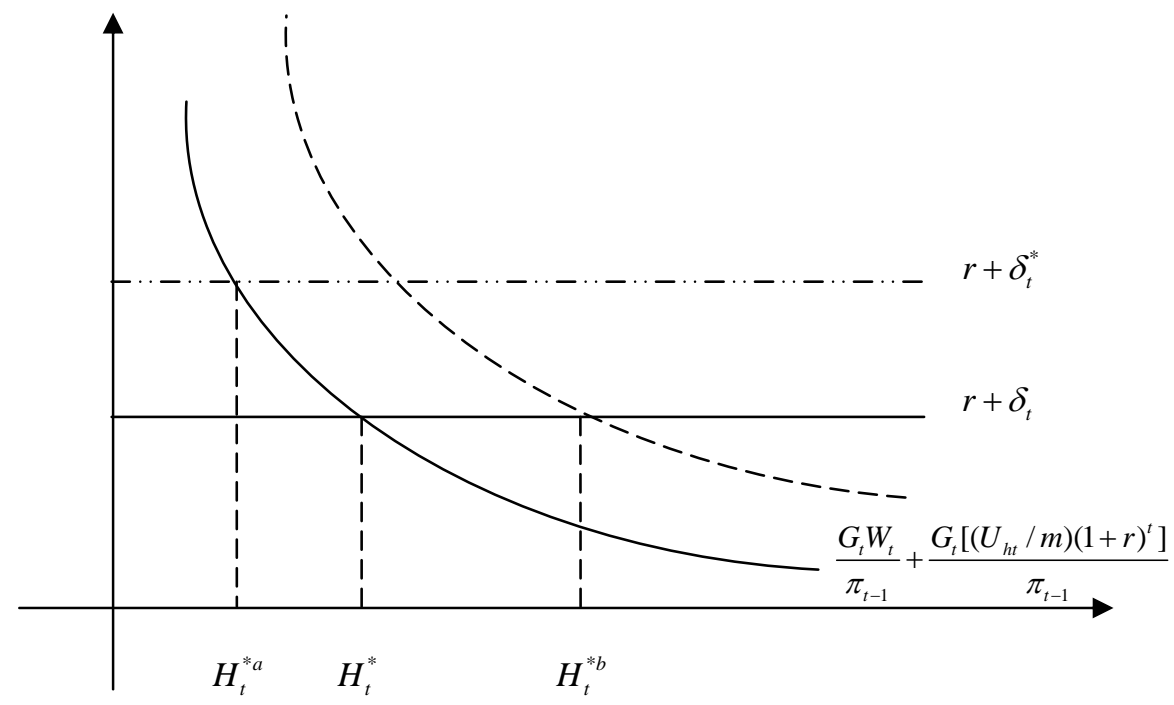


Table 1. Self-Reported Health Status in 2000 by Province, Gender, and City Size

\begin{tabular}{|c|c|c|c|c|c|c|c|c|c|c|c|c|}
\hline & & & $\begin{array}{l}\text { Whole } \\
\text { Sample }\end{array}$ & $\begin{array}{l}\text { Guang- } \\
\mathrm{xi}\end{array}$ & $\begin{array}{l}\text { Gui- } \\
\text { Zhou }\end{array}$ & $\begin{array}{l}\text { He- } \\
\text { Nan }\end{array}$ & $\begin{array}{l}\text { Hu- } \\
\text { Bei }\end{array}$ & $\begin{array}{l}\mathrm{Hu}- \\
\text { nan }\end{array}$ & $\begin{array}{l}\text { Heilong- } \\
\text { jiang }\end{array}$ & $\begin{array}{l}\text { Jiang- } \\
\text { Su }\end{array}$ & $\begin{array}{l}\text { Liao- } \\
\text { ning }\end{array}$ & $\begin{array}{l}\begin{array}{l}\text { Shan- } \\
\text { dong }\end{array} \\
\end{array}$ \\
\hline \multirow{10}{*}{$\begin{array}{l}\frac{\mathscr{c}}{\bar{\Xi}} \\
\text { 心్ }\end{array}$} & \multirow[t]{2}{*}{ Excel } & Freq. & 415 & 12 & 13 & 32 & 40 & 27 & 82 & 65 & 78 & 66 \\
\hline & & $\%$ & $21.0 \%$ & $6.0 \%$ & $5.7 \%$ & $15.0 \%$ & $18.1 \%$ & $10.7 \%$ & $34.5 \%$ & $29.3 \%$ & $38.2 \%$ & $33.7 \%$ \\
\hline & \multirow[t]{2}{*}{ Good } & Freq. & 1036 & 120 & 144 & 117 & 104 & 158 & 124 & 109 & 70 & 90 \\
\hline & & $\%$ & $52.4 \%$ & $60.0 \%$ & $62.6 \%$ & $54.7 \%$ & $47.1 \%$ & $62.7 \%$ & $52.1 \%$ & $49.1 \%$ & $34.3 \%$ & $45.9 \%$ \\
\hline & \multirow[t]{2}{*}{ Fair } & Freq. & 4468 & 61 & 63 & 59 & 64 & 63 & 30 & 45 & 48 & 35 \\
\hline & & $\%$ & $23.7 \%$ & $30.5 \%$ & $27.4 \%$ & $27.6 \%$ & $29.0 \%$ & $25.0 \%$ & $12.6 \%$ & $20.3 \%$ & $23.5 \%$ & $17.9 \%$ \\
\hline & \multirow[t]{2}{*}{ Poor } & Freq. & 58 & 7 & 10 & 6 & 13 & 4 & 2 & 3 & 8 & 5 \\
\hline & & $\%$ & $2.9 \%$ & $3.5 \%$ & $4.3 \%$ & $2.7 \%$ & $5.8 \%$ & $1.6 \%$ & $0.8 \%$ & $1.3 \%$ & $4.0 \%$ & $2.5 \%$ \\
\hline & \multirow[t]{2}{*}{ Total } & Freq. & 1977 & 200 & 230 & 214 & 221 & 252 & 238 & 222 & 204 & 196 \\
\hline & & $\%$ & $100 \%$ & $100 \%$ & $100 \%$ & $100 \%$ & $100 \%$ & $100 \%$ & $100 \%$ & $100 \%$ & $100 \%$ & $100 \%$ \\
\hline \multirow{10}{*}{ 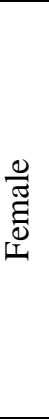 } & \multirow[t]{2}{*}{ Excel } & Freq. & 175 & 2 & 4 & 16 & 16 & 8 & 37 & 28 & 34 & 30 \\
\hline & & $\%$ & $16.8 \%$ & $1.9 \%$ & $3.3 \%$ & $14.0 \%$ & $13.7 \%$ & $6.2 \%$ & $31.1 \%$ & $23.1 \%$ & $29.8 \%$ & $29.1 \%$ \\
\hline & \multirow[t]{2}{*}{ Good } & Freq. & 551 & 61 & 77 & 63 & 47 & 84 & 66 & 63 & 43 & 47 \\
\hline & & $\%$ & $52.8 \%$ & $59.2 \%$ & $63.1 \%$ & $55.3 \%$ & $40.2 \%$ & $64.6 \%$ & $55.5 \%$ & $52.1 \%$ & $37.7 \%$ & $45.6 \%$ \\
\hline & \multirow[t]{2}{*}{ Fair } & Freq. & 284 & 36 & 36 & 33 & 45 & 36 & 15 & 28 & 33 & 22 \\
\hline & & $\%$ & $27.2 \%$ & $35.0 \%$ & $29.5 \%$ & $29.0 \%$ & $38.5 \%$ & $27.7 \%$ & $12.6 \%$ & $23.1 \%$ & $29.0 \%$ & $21.4 \%$ \\
\hline & \multirow[t]{2}{*}{ Poor } & Freq. & 33 & 4 & 5 & 2 & 9 & 2 & 1 & 2 & 4 & 4 \\
\hline & & $\%$ & $3.2 \%$ & $3.9 \%$ & $4.1 \%$ & $1.7 \%$ & $7.6 \%$ & $1.5 \%$ & $0.8 \%$ & $1.7 \%$ & $3.5 \%$ & $3.9 \%$ \\
\hline & \multirow[t]{2}{*}{ Total } & Freq. & 1043 & 103 & 122 & 114 & 117 & 130 & 119 & 121 & 114 & 103 \\
\hline & & $\%$ & $100 \%$ & $100 \%$ & $100 \%$ & $100 \%$ & $100 \%$ & $100 \%$ & $100 \%$ & $100 \%$ & $100 \%$ & $100 \%$ \\
\hline \multirow{10}{*}{$\frac{\frac{0}{\pi}}{\sum^{\frac{\pi}{\Sigma}}}$} & \multirow[t]{2}{*}{ Excel } & Freq. & 240 & 10 & 9 & 16 & 24 & 19 & 45 & 37 & 44 & 36 \\
\hline & & $\%$ & $25.7 \%$ & $10.3 \%$ & $8.3 \%$ & $16.0 \%$ & $23.1 \%$ & $15.6 \%$ & $37.8 \%$ & $36.6 \%$ & $48.9 \%$ & $38.7 \%$ \\
\hline & \multirow[t]{2}{*}{ Good } & Freq. & 485 & 59 & 67 & 54 & 57 & 74 & 58 & 46 & 27 & 43 \\
\hline & & $\%$ & $51.9 \%$ & $60.8 \%$ & $62.0 \%$ & $54.0 \%$ & $54.8 \%$ & $60.7 \%$ & $48.7 \%$ & $45.5 \%$ & $30.0 \%$ & $46.2 \%$ \\
\hline & \multirow[t]{2}{*}{ Fair } & Freq. & 184 & 25 & 27 & 26 & 19 & 27 & 15 & 17 & 15 & 13 \\
\hline & & $\%$ & $19.7 \%$ & $25.8 \%$ & $25.0 \%$ & $26.0 \%$ & $18.3 \%$ & $22.1 \%$ & $12.6 \%$ & $16.9 \%$ & $16.7 \%$ & $14.0 \%$ \\
\hline & \multirow[t]{2}{*}{ Poor } & Freq. & 25 & 3 & 5 & 4 & 4 & 2 & 1 & 1 & 4 & 1 \\
\hline & & $\%$ & $2.7 \%$ & $3.1 \%$ & $4.7 \%$ & $4.0 \%$ & $3.8 \%$ & $1.6 \%$ & $0.9 \%$ & $1.0 \%$ & $4.4 \%$ & $1.1 \%$ \\
\hline & Total & Freq. & 934 & 97 & 108 & 100 & 104 & 122 & 119 & 101 & 90 & 93 \\
\hline & & $\%$ & $100 \%$ & $100 \%$ & $100 \%$ & $100 \%$ & $100 \%$ & $100 \%$ & $100 \%$ & $100 \%$ & $100 \%$ & $100 \%$ \\
\hline & Excel & Freq. & 162 & 5 & 6 & 4 & 13 & 11 & 32 & 13 & 53 & 25 \\
\hline & & $\%$ & $18.2 \%$ & $6.0 \%$ & $5.0 \%$ & $4.0 \%$ & $11.7 \%$ & $9.7 \%$ & $34.4 \%$ & $12.9 \%$ & $61.6 \%$ & $29.4 \%$ \\
\hline & Good & Freq. & 461 & 41 & 70 & 66 & 46 & 71 & 46 & 57 & 14 & 50 \\
\hline$\Xi$ & & $\%$ & $51.7 \%$ & $49.4 \%$ & $58.3 \%$ & $66.0 \%$ & $41.4 \%$ & $62.8 \%$ & $49.5 \%$ & $56.4 \%$ & $16.3 \%$ & $58.8 \%$ \\
\hline ت & Fair & Freq. & 245 & 33 & 41 & 29 & 44 & 29 & 13 & 29 & 17 & 10 \\
\hline & & $\%$ & $27.5 \%$ & $39.8 \%$ & $34.2 \%$ & $29.0 \%$ & $39.6 \%$ & $25.7 \%$ & $14.0 \%$ & $28.7 \%$ & $19.8 \%$ & $11.8 \%$ \\
\hline is & Poor & Freq. & 24 & 4 & 3 & 1 & 8 & 2 & 2 & 2 & 2 & 0 \\
\hline & & $\%$ & $2.6 \%$ & $4.8 \%$ & $2.5 \%$ & $1.0 \%$ & $7.3 \%$ & $1.8 \%$ & $2.1 \%$ & $2.0 \%$ & $2.3 \%$ & $0.0 \%$ \\
\hline & Total & Freq. & 892 & 83 & 120 & 100 & 111 & 113 & 93 & 101 & 86 & 85 \\
\hline & & $\%$ & $100 \%$ & $100 \%$ & $100 \%$ & $100 \%$ & $100 \%$ & $100 \%$ & $100 \%$ & $100 \%$ & $100 \%$ & $100 \%$ \\
\hline & Excel & Freq. & 253 & 7 & 7 & 28 & 27 & 16 & 50 & 52 & 25 & 41 \\
\hline & & $\%$ & $23.3 \%$ & $6.0 \%$ & $6.4 \%$ & $24.6 \%$ & $24.6 \%$ & $11.5 \%$ & $34.5 \%$ & $43.0 \%$ & $21.2 \%$ & $36.9 \%$ \\
\hline & Good & Freq. & 575 & 79 & 74 & 51 & 58 & 87 & 78 & 52 & 56 & 40 \\
\hline & & $\%$ & $53.0 \%$ & $67.5 \%$ & $67.3 \%$ & $44.7 \%$ & $52.7 \%$ & $62.6 \%$ & $53.8 \%$ & $43.0 \%$ & $47.5 \%$ & $36.0 \%$ \\
\hline & Fair & Freq. & 223 & 2 & 22 & 30 & 20 & 34 & 17 & 16 & 31 & 25 \\
\hline & & $\%$ & $20.6 \%$ & $23.9 \%$ & $20.0 \%$ & $26.3 \%$ & $18.2 \%$ & $24.5 \%$ & $11.7 \%$ & $13.2 \%$ & $26.3 \%$ & $22.5 \%$ \\
\hline 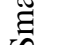 & Poor & Freq. & 34 & 3 & 7 & 5 & 5 & 2 & 0 & 1 & 6 & 5 \\
\hline & & $\%$ & $3.1 \%$ & $2.6 \%$ & $6.3 \%$ & $4.4 \%$ & $4.5 \%$ & $1.4 \%$ & $0.0 \%$ & $0.8 \%$ & $5.0 \%$ & $4.4 \%$ \\
\hline & Total & Freq. & 1,085 & 117 & 110 & 114 & 110 & 139 & 145 & 121 & 118 & 111 \\
\hline & & $\%$ & $100 \%$ & $100 \%$ & $100 \%$ & $100 \%$ & $100 \%$ & $100 \%$ & $100 \%$ & $100 \%$ & $100 \%$ & $100 \%$ \\
\hline
\end{tabular}

Source: Calculated from CHNS 2000 by the author. 
Table 2. Variables Used in the Models

\begin{tabular}{|c|c|c|c|c|c|c|c|}
\hline \multirow[t]{2}{*}{ Variable } & \multirow[t]{2}{*}{ Label } & \multicolumn{2}{|c|}{ Whole } & \multicolumn{2}{|c|}{ Female } & \multicolumn{2}{|c|}{ Male } \\
\hline & & Mean & Std. Dev. & Mean & Std. Dev. & Mean & Std. Dev. \\
\hline FEMALE & Female & 0.5287 & 0.4993 & 1 & 0 & 0 & 0 \\
\hline AGE1 & $18-22$ & 0.0668 & 0.2497 & 0.0604 & 0.2383 & 0.0668 & 0.2497 \\
\hline AGE2 & $23-30$ & 0.1497 & 0.3569 & 0.1486 & 0.3558 & 0.1497 & 0.3569 \\
\hline AGE3 & $31-35$ & 0.1129 & 0.3166 & 0.1151 & 0.3193 & 0.1129 & 0.3166 \\
\hline AGE4 & $36-40$ & 0.1605 & 0.3672 & 0.1588 & 0.3657 & 0.1605 & 0.3672 \\
\hline AGE5 & $41-45$ & 0.1281 & 0.3343 & 0.1281 & 0.3344 & 0.1281 & 0.3343 \\
\hline AGE6 & $46-50$ & 0.1345 & 0.3413 & 0.1411 & 0.3483 & 0.1345 & 0.3413 \\
\hline AGE7 & $51-55$ & 0.0820 & 0.2744 & 0.0826 & 0.2755 & 0.0820 & 0.2744 \\
\hline EDU1 & Elementary school & 0.1547 & 0.3617 & 0.1851 & 0.3885 & 0.1547 & 0.3617 \\
\hline EDU2 & Junior high school & 0.3249 & 0.4684 & 0.3381 & 0.4733 & 0.3249 & 0.4684 \\
\hline EDU3 & Senior high school & 0.3668 & 0.4820 & 0.3579 & 0.4796 & 0.3668 & 0.4820 \\
\hline EDU4 & College and above & 0.1472 & 0.3544 & 0.1114 & 0.3148 & 0.1472 & 0.3544 \\
\hline TW3 & Working time & 23.7688 & 22.9707 & 20.7150 & 22.9576 & 23.7688 & 22.9707 \\
\hline WAGE & Wage & 357.4281 & 684.6482 & 275.3835 & 557.0478 & 357.4281 & 684.6482 \\
\hline HHSIZE & Household size & 3.6942 & 1.1964 & 3.7019 & 1.2010 & 3.6855 & 1.1918 \\
\hline M1 & Insured & 0.3808 & 0.4857 & 0.3537 & 0.4784 & 0.4108 & 0.4922 \\
\hline M21 & Cost of treat a cold & 42.9050 & 42.8810 & 42.7202 & 42.7190 & 43.1123 & 43.0838 \\
\hline HHINCOME & Household income & 6475.716 & 4556.657 & 6459.234 & 4540.838 & 6494.203 & 4576.646 \\
\hline UNDER & Under weight & 0.0633 & 0.2436 & 0.0724 & 0.2593 & 0.0531 & 0.2244 \\
\hline OVER & Over weight & 0.0349 & 0.1835 & 0.0306 & 0.1724 & 0.0396 & 0.1951 \\
\hline WORK & Working? & 0.7295 & 0.4443 & 0.6546 & 0.4757 & 0.8135 & 0.3897 \\
\hline FORMAL & Informal sector & 0.4742 & 0.4995 & 0.4150 & 0.4930 & 0.5406 & 0.4986 \\
\hline BIG & Big city & 0.4600 & 0.4985 & 0.4587 & 0.4985 & 0.4615 & 0.4988 \\
\hline $\mathrm{HIGH}$ & High income city & 0.3697 & 0.4828 & 0.3686 & 0.4827 & 0.3708 & 0.4833 \\
\hline MIDDLE & Mid income city & 0.2528 & 0.4347 & 0.2526 & 0.4347 & 0.2531 & 0.4350 \\
\hline Liaoning & North-Eastern & 0.1006 & 0.3009 & 0.1059 & 0.3078 & 0.0948 & 0.2931 \\
\hline Heilongjiang & North-Eastern & 0.1340 & 0.3408 & 0.1263 & 0.3323 & 0.1427 & 0.3500 \\
\hline Jiangsu & Coastal & 0.1095 & 0.3123 & 0.1133 & 0.3171 & 0.1052 & 0.3070 \\
\hline Shandong & Coastal & 0.1001 & 0.3003 & 0.1003 & 0.3005 & 0.1 & 0.3002 \\
\hline Henan & Middle & 0.1055 & 0.3073 & 0.1068 & 0.3090 & 0.1042 & 0.3056 \\
\hline Hubei & Middle & 0.1109 & 0.3141 & 0.1114 & 0.3148 & 0.1104 & 0.3136 \\
\hline Hunan & Middle & 0.1267 & 0.3327 & 0.1263 & 0.3323 & 0.1271 & 0.3332 \\
\hline Guangxi & Western & 0.0987 & 0.2983 & 0.0966 & 0.2955 & 0.1010 & 0.3015 \\
\hline Guizhou & Western & 0.1139 & 0.3178 & 0.1133 & 0.3171 & 0.1146 & 0.3187 \\
\hline MS & Married & 0.1586 & 0.3654 & 0.1326 & 0.3393 & 0.1878 & 0.3907 \\
\hline $\mathrm{N}$ & Sample Size & & 37 & 10 & & & \\
\hline
\end{tabular}


Table 3. Estimates from Basic Ordered Probit Models (Whole Sample)

\begin{tabular}{|c|c|c|c|c|c|c|c|}
\hline \multicolumn{8}{|c|}{ A. Specification I } \\
\hline \multicolumn{8}{|c|}{ Dependent variable: Self-reporting Health Status } \\
\hline \multirow[t]{2}{*}{ Ind. Variable } & \multirow[t]{2}{*}{ Label } & \multicolumn{2}{|c|}{ Whole } & \multicolumn{2}{|c|}{ Female } & \multicolumn{2}{|c|}{ Male } \\
\hline & & Coefficients & P-value & Coefficients & P-value & Coefficients & P-value \\
\hline FEMALE & Female & -0.2580 & 0.000 & & & & \\
\hline AGE & Age in 2000 & 0.2487 & 0.040 & 0.2735 & 0.110 & 0.2349 & 0.177 \\
\hline AGESQ & Age squared & -0.0074 & 0.026 & -0.0082 & 0.080 & -0.0070 & 0.148 \\
\hline AGECU & Age cubed & 0.000066 & 0.027 & 0.000074 & 0.077 & 0.000060 & 0.165 \\
\hline EDU1 & Elementary school & \multicolumn{6}{|c|}{ Reference Group } \\
\hline EDU2 & Junior high school & 0.2035 & 0.014 & 0.1953 & 0.072 & 0.2425 & 0.062 \\
\hline EDU3 & Senior high school & 0.3167 & 0.000 & 0.3461 & 0.003 & 0.3281 & 0.011 \\
\hline EDU4 & College and above & 0.4506 & 0.000 & 0.6323 & 0.000 & 0.3530 & 0.018 \\
\hline HHSIZE & Household size & 0.0316 & 0.160 & 0.0509 & 0.103 & 0.0160 & 0.624 \\
\hline M1 & Insured & -0.0932 & 0.113 & -0.1757 & 0.034 & -0.0189 & 0.822 \\
\hline M21 & Cost of treat a cold & -0.0007 & 0.268 & -0.0007 & 0.419 & -0.0007 & 0.425 \\
\hline MS & Married & 0.0721 & 0.490 & 0.0349 & 0.812 & 0.1024 & 0.501 \\
\hline Pseudo R-sq & & \multicolumn{2}{|c|}{0.0371} & \multicolumn{2}{|c|}{0.0314} & \multicolumn{2}{|c|}{0.0319} \\
\hline $\mathrm{N}$ & Sample size & \multicolumn{2}{|c|}{1842} & \multicolumn{2}{|c|}{969} & \multicolumn{2}{|c|}{873} \\
\hline \multicolumn{8}{|c|}{ B. Specification II } \\
\hline Ind. Variable & Label & \multicolumn{2}{|c|}{ Whole } & \multicolumn{2}{|c|}{ Female } & \multicolumn{2}{|c|}{ Male } \\
\hline & & Coefficients & P-value & Coefficients & P-value & Coefficients & P-value \\
\hline FEMALE & Female & -0.2478 & 0.000 & - & - & - & - \\
\hline \begin{tabular}{|l|} 
AGE1 \\
\end{tabular} & $18-22$ & \multicolumn{6}{|c|}{ Reference group } \\
\hline \begin{tabular}{|l|} 
AGE2 \\
\end{tabular} & $23-30$ & 0.2231 & 0.010 & \begin{tabular}{l|l}
0.1780 \\
\end{tabular} & 0.136 & 0.2823 & 0.028 \\
\hline AGE3 & 31-35 & 0.1145 & 0.237 & 0.0673 & 0.614 & 0.1826 & 0.198 \\
\hline AGE4 & $36-40$ & 0.0254 & 0.769 & -0.0342 & 0.774 & 0.0955 & 0.449 \\
\hline \begin{tabular}{|l|} 
AGE5 \\
\end{tabular} & $41-45$ & -0.1403 & 0.125 & -0.0129 & 0.919 & -0.2641 & 0.046 \\
\hline \begin{tabular}{|l|} 
AGE6 \\
\end{tabular} & $46-50$ & -0.2662 & 0.004 & -0.2548 & 0.044 & -0.2739 & 0.040 \\
\hline AGE7 & $51-55$ & -0.2558 & 0.019 & -0.1547 & 0.308 & -0.3596 & 0.021 \\
\hline EDU1 & Elementary school & \multicolumn{6}{|c|}{ Reference Group } \\
\hline EDU2 & Junior high school & 0.2348 & 0.004 & 0.2377 & 0.027 & 0.2531 & 0.050 \\
\hline EDU3 & Senior high school & 0.3423 & 0.000 & 0.3784 & 0.001 & 0.3369 & 0.009 \\
\hline EDU4 & College and above & 0.4738 & 0.000 & 0.6897 & 0.000 & 0.3341 & 0.027 \\
\hline HHSIZE & Household size & 0.0398 & 0.076 & 0.0611 & 0.050 & 0.0195 & 0.551 \\
\hline M1 & Insured & -0.1028 & 0.080 & -0.1884 & 0.022 & -0.0264 & 0.753 \\
\hline M21 & Cost of treat a cold & -0.0007 & 0.257 & -0.0007 & 0.412 & -0.0007 & 0.450 \\
\hline MS & Married & 0.1984 & 0.013 & 0.1426 & 0.216 & 0.2272 & 0.046 \\
\hline Pseudo R-sq & & \multicolumn{2}{|c|}{0.0341} & \multicolumn{2}{|c|}{0.0277} & \multicolumn{2}{|c|}{0.0326} \\
\hline $\mathrm{N}$ & Sample size & \multicolumn{2}{|c|}{1842} & \multicolumn{2}{|c|}{969} & \multicolumn{2}{|c|}{873} \\
\hline
\end{tabular}


Table 4. Estimates from More Complicated Ordered Probit Models

(Whole Sample)

\begin{tabular}{|c|c|c|c|c|c|c|c|}
\hline \multicolumn{8}{|c|}{ Dependent variable: Self-reporting Health Status } \\
\hline \multirow{2}{*}{ Ind. Variable } & \multirow{2}{*}{ Label } & \multicolumn{2}{|c|}{ Whole } & \multicolumn{2}{|c|}{ Female } & \multicolumn{2}{|c|}{ Male } \\
\hline & & Coefficients & P-value & Coefficients & P-value & Coefficients & P-value \\
\hline FEMALE & Female & -0.2683 & 0.000 & - & - & - & - \\
\hline AGE1 & $18-22$ & \multicolumn{6}{|c|}{ Reference Group } \\
\hline AGE2 & 23-30 & 0.2162 & 0.015 & 0.1532 & 0.210 & 0.2701 & 0.040 \\
\hline AGE3 & 31-35 & 0.1144 & 0.243 & 0.0679 & 0.615 & 0.1647 & 0.256 \\
\hline AGE4 & $36-40$ & 0.0117 & 0.894 & -0.0468 & 0.700 & 0.0571 & 0.658 \\
\hline AGE5 & $41-45$ & -0.0999 & 0.282 & 0.0189 & 0.884 & -0.2282 & 0.090 \\
\hline AGE6 & $46-50$ & -0.2715 & 0.004 & -0.3326 & 0.010 & -0.2050 & 0.132 \\
\hline AGE7 & $51-55$ & -0.2639 & 0.017 & -0.2497 & 0.107 & -0.2868 & 0.073 \\
\hline EDU1 & Elementary school & \multicolumn{6}{|c|}{ Reference Group } \\
\hline EDU2 & Junior high school & 0.1713 & 0.042 & 0.1250 & 0.259 & 0.2064 & 0.119 \\
\hline EDU3 & Senior high school & 0.2425 & 0.006 & 0.2259 & 0.057 & 0.2516 & 0.060 \\
\hline EDU4 & College and above & 0.3053 & 0.007 & 0.4778 & 0.004 & 0.1921 & 0.238 \\
\hline HHSIZE & Household size & 0.0751 & 0.002 & 0.0995 & 0.003 & 0.0601 & 0.093 \\
\hline M1 & Insured & -0.0557 & 0.375 & -0.1545 & 0.079 & 0.0451 & 0.621 \\
\hline M21 & Cost of treat a cold & -0.0018 & 0.014 & -0.0015 & 0.133 & -0.0022 & 0.045 \\
\hline HHINCOME & Household income & 0.0000053 & 0.404 & 0.0000043 & 0.625 & 0.0000048 & 0.603 \\
\hline BIG & Big city & 0.1141 & 0.126 & 0.1816 & 0.079 & 0.0398 & 0.717 \\
\hline HIGH & High income city & -0.0385 & 0.548 & -0.1111 & 0.210 & 0.0393 & 0.674 \\
\hline MIDDLE & Mid income city & 0.3329 & 0.000 & 0.2326 & 0.035 & 0.4552 & 0.000 \\
\hline Liaoning & North-Eastern & 0.3992 & 0.001 & 0.2382 & 0.124 & 0.5921 & 0.001 \\
\hline Heilongjiang & North-Eastern & 0.5766 & 0.000 & 0.6210 & 0.000 & 0.5648 & 0.001 \\
\hline Jiangsu & Coastal & 0.4086 & 0.000 & 0.3293 & 0.037 & 0.5163 & 0.003 \\
\hline Shandong & Coastal & 0.5395 & 0.000 & 0.4558 & 0.005 & 0.6493 & 0.000 \\
\hline Henan & Middle & \multicolumn{6}{|c|}{ Reference Group } \\
\hline Hubei & Middle & -0.0162 & 0.889 & -0.2463 & 0.121 & 0.2256 & 0.192 \\
\hline Hunan & Middle & 0.0842 & 0.466 & 0.0089 & 0.955 & 0.1553 & 0.356 \\
\hline Guangxi & Western & -0.2324 & 0.040 & -0.2944 & 0.060 & -0.1583 & 0.336 \\
\hline Guizhou & Western & -0.2352 & 0.032 & -0.2605 & 0.083 & -0.2374 & 0.143 \\
\hline MS & Married & 0.2611 & 0.001 & 0.2051 & 0.080 & 0.2992 & 0.010 \\
\hline Pseudo R-sq & & \multicolumn{2}{|c|}{0.0696} & \multicolumn{2}{|c|}{0.0647} & \multicolumn{2}{|c|}{0.0749} \\
\hline $\mathrm{N}$ & Sample size & \multicolumn{2}{|c|}{1842} & \multicolumn{2}{|c|}{969} & \multicolumn{2}{|c|}{873} \\
\hline
\end{tabular}


Table 5. Estimates from More Complicated Ordered Probit Models (Working Sample)

\begin{tabular}{|c|c|c|c|c|c|c|c|}
\hline \multicolumn{8}{|c|}{ Dependent variable: Self-reporting Health Status } \\
\hline \multirow[t]{2}{*}{ Ind. Variable } & \multirow[t]{2}{*}{ Label } & \multicolumn{2}{|c|}{ Whole } & \multicolumn{2}{|c|}{ Female } & \multicolumn{2}{|c|}{ Male } \\
\hline & & Coefficients & P-value & Coefficients & P-value & Coefficients & P-value \\
\hline FEMALE & Female & -0.2985 & 0.000 & - & - & - & - \\
\hline AGE1 & $18-22$ & \multicolumn{6}{|c|}{ Reference Group } \\
\hline AGE2 & $23-30$ & 0.2012 & 0.056 & 0.1587 & 0.294 & 0.2509 & 0.098 \\
\hline AGE3 & 31-35 & 0.1270 & 0.260 & 0.0977 & 0.547 & 0.1644 & 0.309 \\
\hline AGE4 & $36-40$ & 0.0106 & 0.915 & 0.0436 & 0.762 & -0.0167 & 0.905 \\
\hline AGE5 & $41-45$ & -0.1579 & 0.137 & -0.0185 & 0.908 & -0.2648 & 0.068 \\
\hline AGE6 & $46-50$ & -0.2726 & 0.015 & -0.2148 & 0.209 & -0.2987 & 0.049 \\
\hline AGE7 & $51-55$ & -0.3475 & 0.016 & -0.1250 & 0.596 & -0.4461 & 0.017 \\
\hline EDU1 & Elementary school & \multicolumn{6}{|c|}{ Reference Group } \\
\hline EDU2 & Junior high school & 0.1978 & 0.072 & 0.0904 & 0.572 & 0.2509 & 0.104 \\
\hline EDU3 & Senior high school & 0.3568 & 0.001 & 0.3273 & 0.048 & 0.3596 & 0.021 \\
\hline EDU4 & College and above & 0.3712 & 0.006 & 0.6182 & 0.003 & 0.1937 & 0.288 \\
\hline TW3 & Working time & 0.0008 & 0.646 & 0.0038 & 0.114 & -0.0026 & 0.277 \\
\hline WAGE & Wage & 0.000036 & 0.453 & 0.000102 & 0.227 & 0.000011 & 0.862 \\
\hline HHSIZE & Household size & 0.0667 & 0.024 & 0.0974 & 0.030 & 0.0503 & 0.212 \\
\hline M1 & Insured & -0.1469 & 0.063 & -0.3389 & 0.004 & -0.0114 & 0.917 \\
\hline M21 & Cost of treat a cold & -0.0026 & 0.005 & -0.0026 & 0.070 & -0.0027 & 0.027 \\
\hline HHINCOME & Household income & 0.0000021 & 0.804 & -0.0000052 & 0.665 & 0.0000063 & 0.586 \\
\hline FORMAL & In formal sector & 0.0702 & 0.384 & 0.0616 & 0.598 & 0.0916 & 0.423 \\
\hline BIG & Big city & 0.0972 & 0.281 & 0.0505 & 0.707 & 0.0865 & 0.490 \\
\hline HIGH & High income city & -0.0377 & 0.618 & -0.1253 & 0.262 & 0.0233 & 0.825 \\
\hline MIDDLE & Mid income city & 0.2253 & 0.019 & -0.0385 & 0.789 & 0.4005 & 0.002 \\
\hline Liaoning & North-Eastern & 0.3037 & 0.030 & 0.1047 & 0.608 & 0.5274 & 0.008 \\
\hline Heilongjiang & North-Eastern & 0.5036 & 0.000 & 0.5587 & 0.006 & 0.5181 & 0.006 \\
\hline Jiangsu & Coastal & 0.4081 & 0.004 & 0.3894 & 0.066 & 0.4913 & 0.011 \\
\hline Shandong & Coastal & 0.5435 & 0.000 & 0.4731 & 0.041 & 0.6462 & 0.002 \\
\hline Henan & Middle & \multicolumn{6}{|c|}{ Reference Group } \\
\hline Hubei & Middle & -0.1551 & 0.279 & -0.4602 & 0.031 & 0.1100 & 0.580 \\
\hline Hunan & Middle & 0.0858 & 0.544 & -0.0059 & 0.979 & 0.1504 & 0.421 \\
\hline Guangxi & Western & -0.2569 & 0.065 & -0.2487 & 0.227 & -0.2535 & 0.187 \\
\hline Guizhou & Western & -0.2649 & 0.044 & -0.2166 & 0.268 & -0.3317 & 0.067 \\
\hline MS & Married & 0.1869 & 0.069 & 0.0233 & 0.878 & 0.2756 & 0.055 \\
\hline Pseudo R-sq & & \multicolumn{2}{|c|}{0.0734} & \multicolumn{2}{|c|}{0.0773} & \multicolumn{2}{|c|}{0.0819} \\
\hline $\mathrm{N}$ & Sample size & \multicolumn{2}{|c|}{1356} & \multicolumn{2}{|c|}{638} & \multicolumn{2}{|c|}{718} \\
\hline
\end{tabular}




\section{Table 6. Estimates from More Complicated Ordered Probit Models by Sector}

(Working Sample)

\begin{tabular}{|c|c|c|c|c|c|c|c|}
\hline \multicolumn{8}{|c|}{ Dependent variable: Self-reporting Health Status } \\
\hline \multirow[t]{2}{*}{ Ind. Variable } & \multirow[t]{2}{*}{ Label } & \multicolumn{2}{|c|}{ Whole } & \multicolumn{2}{|c|}{ Formal Sector } & \multicolumn{2}{|c|}{ Informal Sector } \\
\hline & & Coefficients & P-value & Coefficients & P-value & Coefficients & P-value \\
\hline FEMALE & Female & -0.2985 & 0.000 & -0.2879 & 0.000 & -0.2694 & 0.010 \\
\hline AGE1 & $18-22$ & \multicolumn{6}{|c|}{ Reference Group } \\
\hline AGE2 & $23-30$ & 0.2012 & 0.056 & 0.2523 & 0.078 & 0.0558 & 0.732 \\
\hline AGE3 & 31-35 & 0.1270 & 0.260 & 0.1971 & 0.151 & -0.0310 & 0.884 \\
\hline AGE4 & $36-40$ & 0.0106 & 0.915 & 0.1109 & 0.382 & -0.1372 & 0.406 \\
\hline AGE5 & $41-45$ & -0.1579 & 0.137 & -0.1603 & 0.245 & -0.1588 & 0.354 \\
\hline AGE6 & $46-50$ & -0.2726 & 0.015 & -0.3042 & 0.029 & -0.1478 & 0.453 \\
\hline AGE7 & $51-55$ & -0.3475 & 0.016 & -0.1915 & 0.303 & -0.6322 & 0.009 \\
\hline EDU1 & Elementary school & \multicolumn{6}{|c|}{ Reference Group } \\
\hline EDU2 & Junior high school & 0.1978 & 0.072 & 0.1834 & 0.327 & 0.2498 & 0.075 \\
\hline EDU3 & Senior high school & 0.3568 & 0.001 & 0.3648 & 0.042 & 0.3890 & 0.015 \\
\hline EDU4 & College and above & 0.3712 & 0.006 & 0.4101 & 0.037 & 0.4219 & 0.118 \\
\hline TW3 & Working time & 0.0008 & 0.646 & -0.0002 & 0.944 & -0.0005 & 0.812 \\
\hline WAGE & Wage & 0.000036 & 0.453 & 0.000025 & 0.684 & 0.000050 & 0.531 \\
\hline HHSIZE & Household size & 0.0667 & 0.024 & 0.0735 & 0.068 & 0.0466 & 0.313 \\
\hline M1 & Insured & -0.1469 & 0.063 & -0.1272 & 0.179 & -0.1507 & 0.364 \\
\hline M21 & Cost of treat a cold & -0.0026 & 0.005 & -0.0026 & 0.016 & -0.0036 & 0.069 \\
\hline HHINCOME & Household income & 0.0000021 & 0.804 & -0.0000093 & 0.387 & 0.000024 & 0.075 \\
\hline FORMAL & In formal sector & 0.0702 & 0.384 & - & - & - & - \\
\hline $\mathrm{BIG}$ & Big city & 0.0972 & 0.281 & 0.1034 & 0.384 & 0.1212 & 0.426 \\
\hline HIGH & High income city & -0.0377 & 0.618 & -0.0990 & 0.305 & 0.0189 & 0.898 \\
\hline MIDDLE & Mid income city & 0.2253 & 0.019 & 0.1986 & 0.145 & 0.2357 & 0.116 \\
\hline Liaoning & North-Eastern & 0.3037 & 0.030 & 0.6355 & 0.000 & -0.3754 & 0.151 \\
\hline Heilongjiang & North-Eastern & 0.5036 & 0.000 & 0.6144 & 0.000 & 0.8302 & 0.013 \\
\hline Jiangsu & Coastal & 0.4081 & 0.004 & 0.5283 & 0.004 & 0.3536 & 0.158 \\
\hline \begin{tabular}{|l|} 
Shandong \\
\end{tabular} & Coastal & 0.5435 & 0.000 & 0.7979 & 0.000 & 0.2913 & 0.248 \\
\hline Henan & Middle & \multicolumn{6}{|c|}{ Reference Group } \\
\hline Hubei & Middle & -0.1551 & 0.279 & 0.0409 & 0.825 & -0.4342 & 0.078 \\
\hline Hunan & Middle & 0.0858 & 0.544 & 0.2136 & 0.269 & -0.1676 & 0.446 \\
\hline Guangxi & Western & -0.2569 & 0.065 & -0.1983 & 0.318 & -0.4427 & 0.038 \\
\hline Guizhou & Western & -0.2649 & 0.044 & -0.0823 & 0.624 & -0.4980 & 0.025 \\
\hline MS & Married & 0.1869 & 0.069 & 0.3824 & 0.009 & -0.0253 & 0.866 \\
\hline Pseudo R-sq & & \multicolumn{2}{|c|}{0.0734} & \multicolumn{2}{|c|}{0.0773} & \multicolumn{2}{|c|}{0.0855} \\
\hline $\mathrm{N}$ & Sample size & \multicolumn{2}{|c|}{1356} & \multicolumn{2}{|c|}{638} & \multicolumn{2}{|c|}{865} \\
\hline
\end{tabular}

